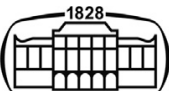

AKADÉMIAI KIADÓ

Pollack Periodica

An International Journal

for Engineering and Information Sciences

$16(2021) 3,108-113$

DOI:

10.1556/606.2021.00377

(c) 2021 The Author(s)

\section{ORIGINAL RESEARCH} PAPER

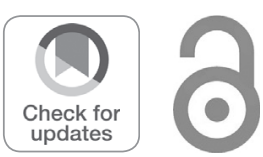

Corresponding author.

E-mail: hajdfl@sze.hu

\title{
Heat radiation effects on insulating materials used in buildings
}

\author{
Flóra Hajdu ${ }^{1 *} \odot$, Gabriella Lászlo ${ }^{2}$ and Rajmund Kuti $^{1}$
}

\author{
${ }^{1}$ Department of Mechatronics and Machine Design, Faculty of Mechanical Engineering, Informatics \\ and Electrical Engineering, Szécsenyi István University, Egyetem tér 1, H-9026 Győr, Hungary \\ ${ }^{2}$ Doctoral School of Multidisciplinary Engineering Sciences, Széchenyi István University, Egyetem tér \\ 1, H-9026 Györ, Hungary
}

Received: December 31, 2020 • Revised manuscript received: April 7, 2021 • Accepted: April 10, 2021 Published online: May 29, 2021

\begin{abstract}
In recent years, in order to increase the energy efficiency of older buildings in Hungary, several tenders have supported the modernization of the thermal insulation. Various thermal insulation materials have been installed on walls, on slab and on floor. Unfortunately there are cases where thermal insulation materials are not installed in accordance with the construction permit or the manufacturer's instructions, which poses a serious danger in case of a fire. During the research the effects of heat on the behavior of Expanded PolyStyrene, a thermal insulation material often used in Hungary is examined. Laboratory tests and computer simulations were carried out, which are presented in detail in this paper. The aim of the research is to contribute to increase the fire safety of buildings.
\end{abstract}

\section{KEYWORDS}

insulating materials, indoor fire, heat measurement, simulation

\section{INTRODUCTION}

Fires occur quite often in various buildings in Hungary, therefore fire protection of building materials is an important, current issue [1]. Modernization of existing buildings will become topical after a certain period of time, during which the fire protection aspects must also be met. Knowledge of fire protection properties of the installed materials and application of the appropriate installation technology is extremely important in fire protection practice. One of the significant steps in the modernization of buildings is to increase their thermal insulation, which in case of old buildings is realized posteriorly. In the last two decades the government has also supported energy modernization, which has resulted in the thermal insulation of a large number of old buildings. One of the frequently used thermal insulation materials was Expanded PolyStyrene (EPS), which must be installed according to a separate standard [2]. Unfortunately, in practice, the installation regulations were not always followed by the contractors and it was only revealed during fires [3, 4]. It turned out for example that EPS was used not only for external thermal insulation, but also for internal thermal insulation placed over a built-in suspended ceiling or used as a sound insulation in a nightclub behind a similar perforated plate. EPS should not be used indoors because the direct combustion of it produces large amounts of toxic combustion products, like $\mathrm{CO}$ (carbon-monoxide), $\mathrm{CO}_{2}$ (carbon-dioxide), $\mathrm{HBr}$ (hydrogen-bromide), $\mathrm{HCl}$ (hydrogen-chloride), $\mathrm{SO}_{2}$ (sulfur-dioxide), which reduces the chances of survival of people in the fire-affected room [5]. The aim of the research is to investigate the changes in the EPS material due to direct heat in laboratory environment. Using results of the measurement the development of computer simulation has also been initialized in order to help to understand the phenomena more accurately and also contribute to the planning of future research tasks. 


\section{LABORATORY MEASUREMENTS}

In practice it was observed that deformations had occurred in the EPS insulations due to radiant heat. The standard tests mostly examine the ignitability and fire properties of materials [6], therefore a different laboratory experiment was performed to examine the temperature increase and the mass loss of EPS. In the scientific literature some examples of examining the behavior of EPS due to radiant heat can be found. However, different measurement devices and methods were used and different phenomena were investigated in these papers (e.g., the effect of solar radiation, the effect of sample width, etc.) [7-10]. During the experiment presented in this paper the temperature of the heat source can be adjusted precisely and the heat radiation reaching the surface of the EPS sample can be measured accurately, therefore the internal temperature change of EPS can be effectively detected.

Before starting the laboratory measurements, the properties connected to fire protection of the selected EPS were studied. During production of EPS thermal insulation material pentane $\left(\mathrm{C}_{5} \mathrm{H}_{12}\right)$ is added to polymerized styrene as a first step. During the expansion, water vapor is introduced into the polystyrene granules and as a result the particles of the raw material soften. As the temperature increases, the pentane propellant swells the polystyrene beads 20-50-fold while forming tiny, closed cells within the polystyrene beads. The expanded polystyrene cannot be used immediately; a blocking process is required first. The surface of the beads hardens due to cooling, the propellant contracts and air diffuses into the formed cells. During rest moisture added during steaming evaporates from the beads. The pre-foamed beads are then re-steamed in a closed form, during which the beads are pressed together to form a homogeneous block without binder. After resting, these blocks are cut to size [11].

EPS is a thermoplastic material, therefore at higher temperatures (above $+80{ }^{\circ} \mathrm{C}$ ) its load capacity and dimensional stability deteriorate and it deforms under the influence of heat. Therefore is not recommended for use in places permanently exposed to temperatures above $+70{ }^{\circ} \mathrm{C}$. EPS used for thermal insulation is treated with a flame retardant, therefore the material does not burn on its own after the ignition source or direct fire has been extinguished. Thermal properties EPS are summarized in Table 1.

Table 1. Thermal properties of EPS (by Authors bases on [12])

\begin{tabular}{lcc}
\hline Property & Unit & Value \\
\hline Density $(\rho)$ & $\mathrm{kg} / \mathrm{m}^{3}$ & $15-30$ \\
Compressive strength $(\sigma c)$ & $\mathrm{kPa}$ & $30-300$ \\
Tensile strength $(\sigma t)$ & $\mathrm{kPa}$ & $100-300$ \\
Water uptake $(W)$ & $\mathrm{kg} / \mathrm{m}^{2}$ & $1-5$ \\
Thermal conductivity $(\lambda)$ & $\mathrm{W} / \mathrm{m} \mathrm{K}$ & $0.032-0.040$ \\
Melting point $(\mathrm{TO})$ & ${ }^{\circ} \mathrm{C}$ & $80-85$ \\
Ignition temperature $(\mathrm{TGY})$ & ${ }^{\circ} \mathrm{C}$ & $346-405$ \\
Heating value $(\mathrm{HV})$ & $\mathrm{kJ} / \mathrm{kg}$ & 42,000 \\
\hline
\end{tabular}

Measurements were performed with an adjustable temperature heat source with heat sensors placed in front of it and in the test specimen and a six-channel data logger. The measurement results were recorded by a computer connected to the device. The measuring equipment and the sketch of the measurement are shown in Fig. 1.

Samples with a uniform width of $10 \times 10 \mathrm{~cm}$ and a length corresponding to the material thickness were prepared. In each sample thermocouples were placed $3 \mathrm{~cm}$ apart at a depth of $5 \mathrm{~cm}$ from the side, and then the sample was fixed to holder stand $5 \mathrm{~cm}$ in front of the heat source. During the measurements, the heat source was set to a temperature of $500{ }^{\circ} \mathrm{C}$. The temperature sensor in front of the sample (fixed on the sample holder stand) measured a temperature of $100{ }^{\circ} \mathrm{C}$ because of the air gap between the
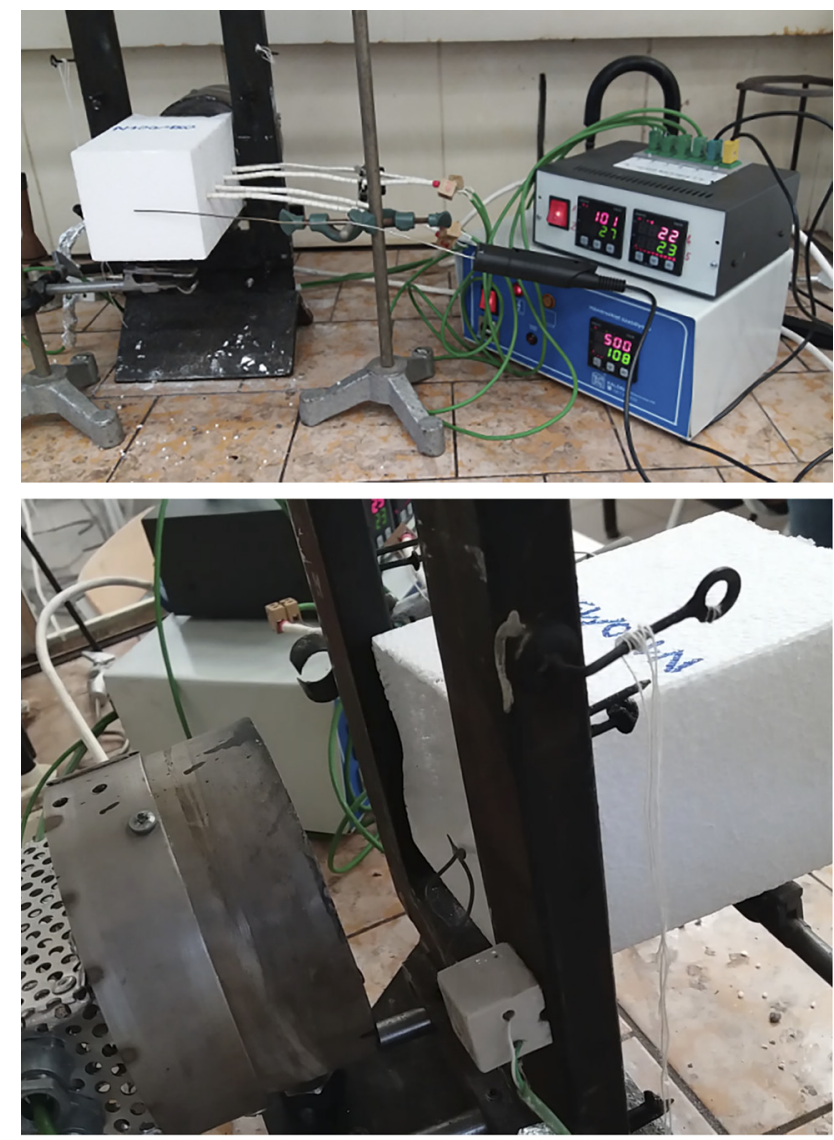

heat source $\left(500^{\circ} \mathrm{C}\right)$

1st measurement point $\left(100^{\circ} \mathrm{C}\right)$ supporting frame
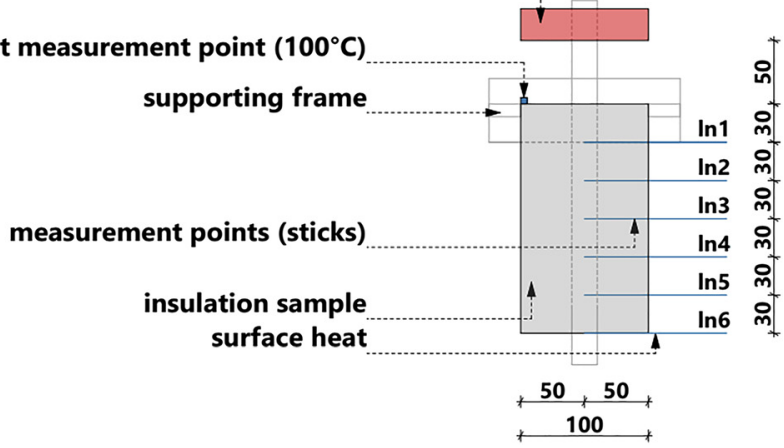

Fig. 1. Measurement device (up) and measurement sketch (down) 
heat source and the device. At the beginning of the measurement, the thermal insulation sheet was removed and then the sample was exposed to radiant heat at $100{ }^{\circ} \mathrm{C}$ for a period of $10 \mathrm{~min}$ and in the case of a $20 \mathrm{~cm}$ wide sample for $16 \mathrm{~min}$.

During measurements it was experienced that after approximately 3 and 6 min the temperature was above 120$140{ }^{\circ} \mathrm{C}$ at the first temperature sensor placed into the sample, which suggests that in the EPS samples exothermic processes start after a short period of time at temperature $100{ }^{\circ} \mathrm{C}$. The measurement results are shown in Figs 2-4.

Analyzing the results, it can be stated that after 3-4 min, the temperature measured by the first sensor in both the 12 and $15 \mathrm{~cm}$ samples exceeded the temperature of $100{ }^{\circ} \mathrm{C}$, and then further increased to approximately $120^{\circ} \mathrm{C}$. In case of the second sensor it took 6-7 $\mathrm{min}$ to reach a temperature of $100{ }^{\circ} \mathrm{C}$. By the end of the measurement time, the temperature measured at the second sensor approached $120{ }^{\circ} \mathrm{C}$ with no further increase. However the temperature measured by the first sensor has started to decrease. No flame combustion occurred, but mild smoke was observed in all experiments.

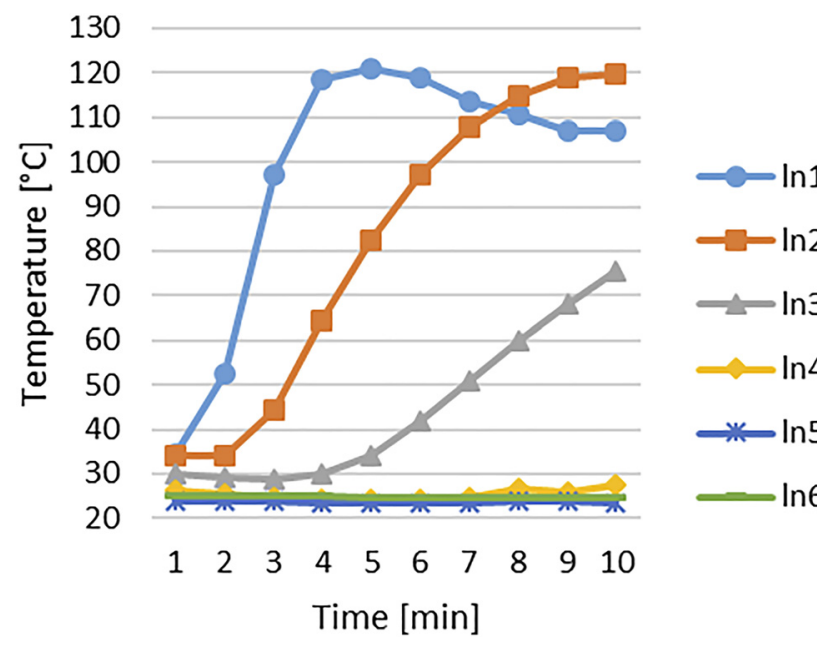

Fig. 2. Measurement results of the EPS sample with $12 \mathrm{~cm}$ width

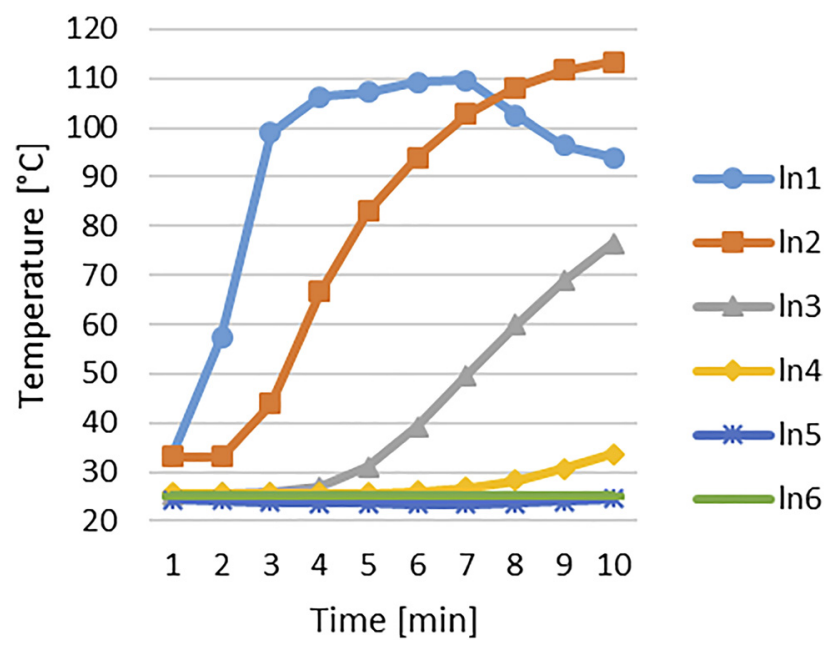

Fig. 3. Measurement results of the EPS sample with $15 \mathrm{~cm}$ width

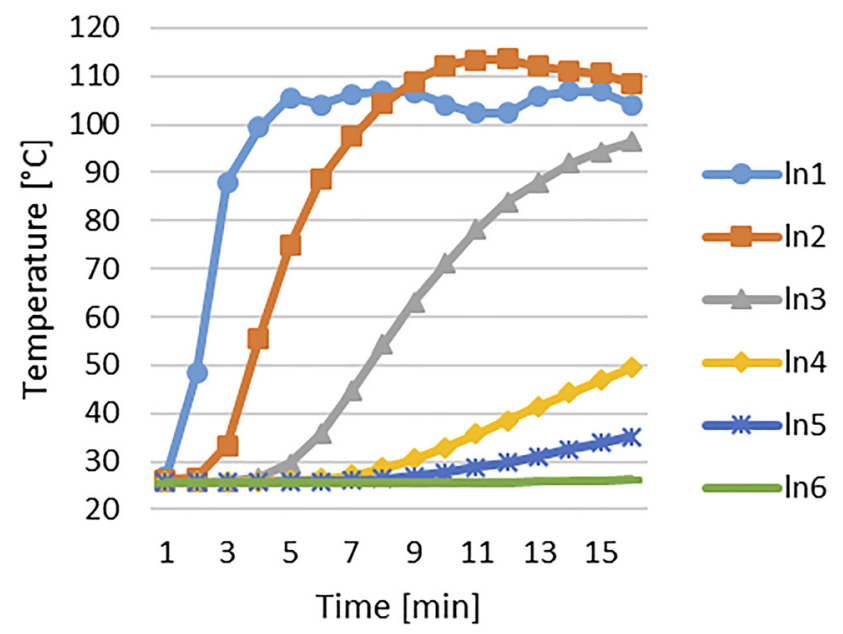

Fig. 4. Measurement results of the EPS sample with $20 \mathrm{~cm}$ width

In case of the $20 \mathrm{~cm}$ thick sample it can be seen that after 3-4 $\mathrm{min}$ the temperature measured by the first sensor reached $100{ }^{\circ} \mathrm{C}$, then increased further to approximately 110 ${ }^{\circ} \mathrm{C}$. The temperature measured by the second sensor exceeded the temperature measured by the first sensor after $8 \mathrm{~min}$ and further increased to $115^{\circ} \mathrm{C}$, then decreased continuously until the end of the measurement.

The weight of each sample was measured before and after the measurement and the results are shown in the following Table 2.

Analyzing the results it can be concluded that the exothermic processes in the samples were accompanied by weight loss and deformation, which can be clearly seen in Fig. 5. Smoke was also experienced during the measurements. Combustion with a flame did not occur, only oxidation happened.

\section{COMPUTER SIMULATION}

Finite element simulations can be effectively used to examine fire behavior of building elements and materials [13]. In this research Fire Dynamic Simulator (FDS) was used [14], which was already used effectively to simulate indoor fires [15-18]. The simulation environment was set up based on the measurement described in Section 2. The temperature rise in the measurement points and the material loss were examined. The simulation environment was $120 \times$ $220 \times 130 \mathrm{~mm}$ open space. The temperature at surface $\mathrm{y}=0$ was $500{ }^{\circ} \mathrm{C}$. The mesh size was $5 \times 5 \times 5 \mathrm{~mm}$. The simulation time was $600 \mathrm{~s}$ according to the measurement time. The simulation model is shown is Fig. 6.

Table 2. Mass change of samples during the experiments

\begin{tabular}{lccc}
\hline Size $(\mathrm{mm})$ & Mass $(\mathrm{g})$ & Mass loss $(\mathrm{g})$ & Mass loss $\%$ \\
\hline $100 \times 100 \times 120$ & 18.22 & 0.14 & 0.774 \\
$100 \times 100 \times 150$ & 24.98 & 0.26 & 1.051 \\
$100 \times 100 \times 200$ & 30.05 & 0.24 & 0.805 \\
\hline
\end{tabular}



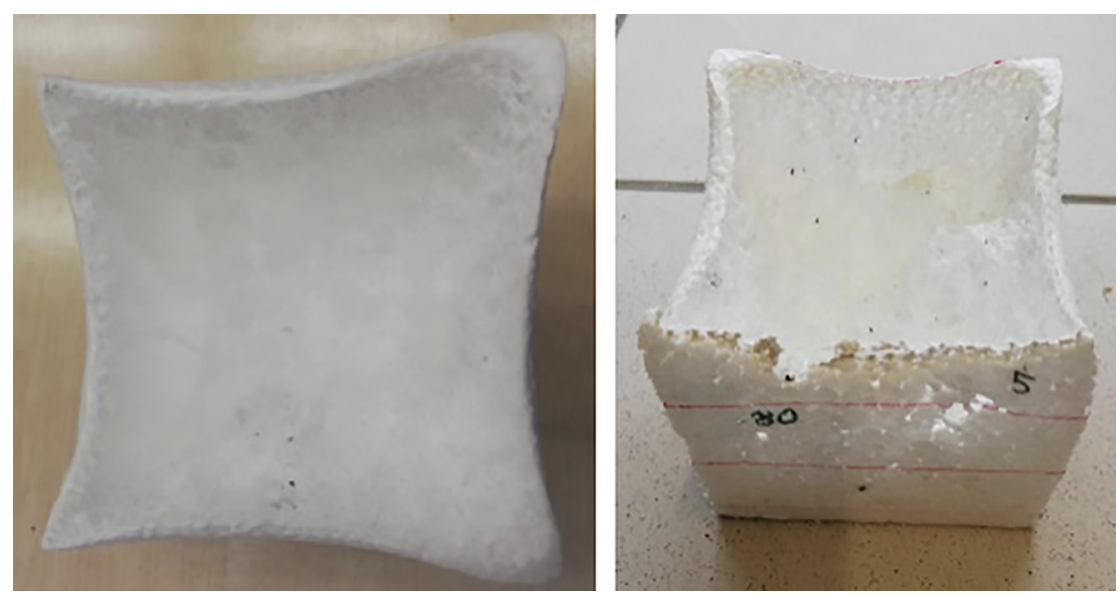

Fig. 5. Deformation of the EPS sample due heat
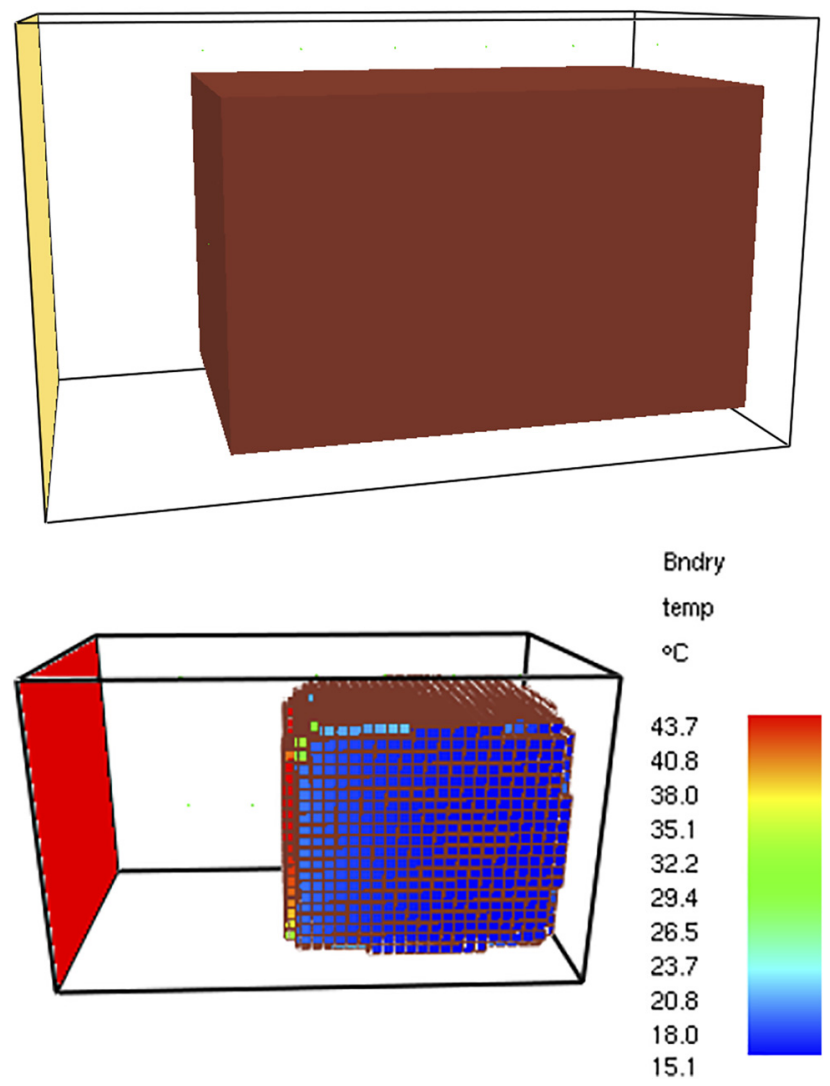

Fig. 6. Simulation model

Temperature sensors were placed according to the measurement set-up shown in Fig. 1. The simulation results are shown in Fig. 7.

It can be seen that in case of the first sensor (which is placed at the supporting frame in case of the measurement) the temperature rises to $101.24{ }^{\circ} \mathrm{C}$ similarly to the measurement. The maximum temperature is reached after $33.6 \mathrm{~s}$. In case of the second sensor (which is the first sensor placed inside the sample) the temperature rises till $85.3^{\circ} \mathrm{C}$ after $228 \mathrm{~s}$. Therefore the maximum temperature is

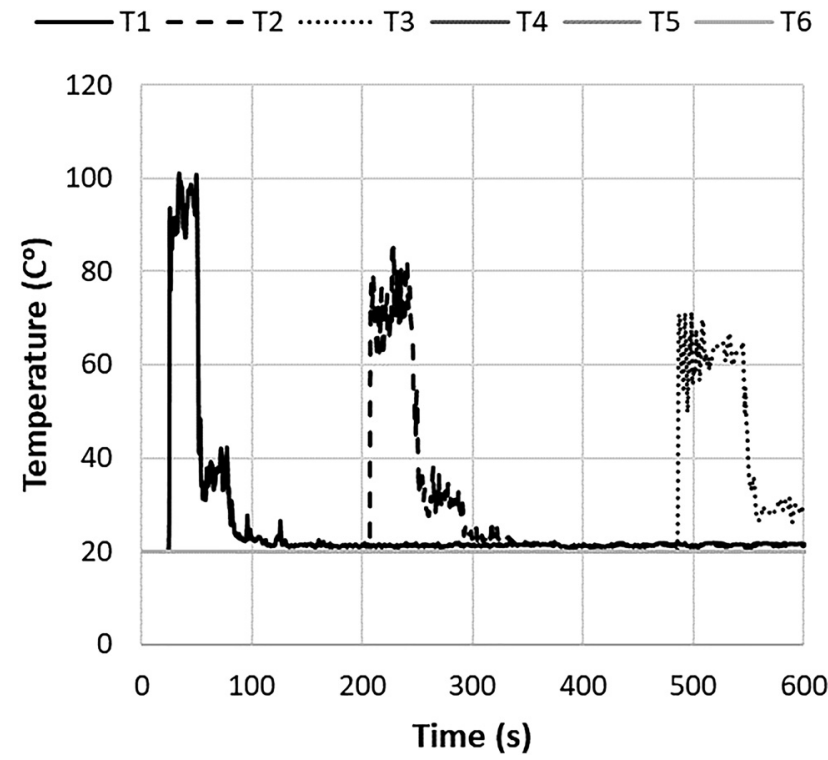

Fig. 7. Simulation results

reached approximately $3 \mathrm{~min}$ after the surface of the sample reached $100{ }^{\circ} \mathrm{C}$. The maximum temperature in case of the third sensor (second placed inside the sample) is $71.34 \mathrm{~s}$ and is reached after $492 \mathrm{~s}$. Therefore the maximum temperature was reached after $7.6 \mathrm{~min}$. The time to reach the maximum temperature is similar to the measurement. The maximum temperature is smaller, because the material was burned and the air temperature decreased because of the open space. Also there remained less material to burn and to increase the temperature further. In case of the other sensors there was no temperature change. It is because the material was not burned therefore the temperature of the combustion gases could not be measured. The mass loss was also estimated, which was $58 \%$. It is much more than in case of the measurement. Therefore the simulation model should be improved in the future to capture the exotherm phenomena inside the EPS material more accurately. 


\subsection{Simulation of a room with insulating material}

The results presented above can also be used in the development of simulations of indoor fires. To begin with the research two types of preliminary simulation models were already created, which are shown in Fig. 8.
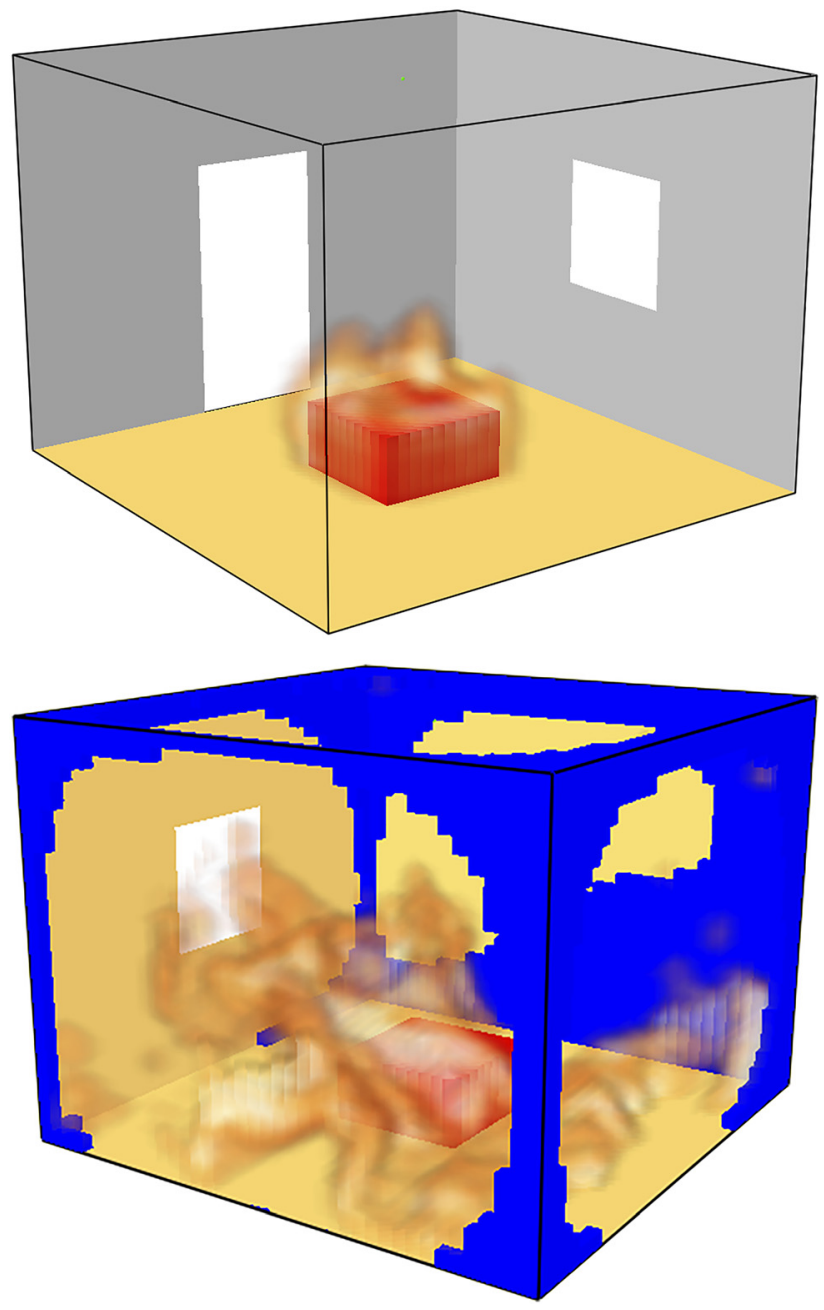

Fig. 8. Simulation of indoor fire with insulating material (up: insulating material defined as wall, down: insulating material defined as object)
The wall temperature was measured, the simulation time was $60 \mathrm{~s}$. The room and the fire model were based on [19]. In the first case the insulating material was specified as wall. In this case the heat load and the temperature of the walls and the room can be examined (Fig. 9).

In the second case the insulating material was modeled as a separate object. The advantage of this model, those combustion properties can also be specified. With this model the combustion of the insulating material, fire spread and fire damage can be examined (Fig. 10).

These simulations were run on a simple laptop. Using a rough mesh the calculation time was $32 \mathrm{~min}$ in the first case and $60 \mathrm{~min}$ in the second case. It is an ongoing research; therefore it is yet to decide which simulation model will be used to model indoor fires.

\section{CONCLUSION}

Continuous testing of insulating materials is very important to increase fire safety of buildings. Research results in the topic also contribute to the further development of products and materials. The performed experiments revealed that exothermic processes start in the examined EPS samples under the influence of heat even at $100{ }^{\circ} \mathrm{C}$, which is accompanied by smoke formation. Knowing the properties of the insulating material, it can be concluded that smoke contains substances, which are harmful to human health. Therefore the use of EPS materials is not recommended indoors for either heat or sound insulation. The examined samples were the thickest available in order to observe the phenomena more accurately. At the same time a thinner sample loses its weight much sooner (penetrates) due to direct heat load as a result of which the building structure or equipment protected by it receives the heat load, which may even lead to fire. In the course of the presented research work it can be concluded that laboratory experiments are essential to create simulations that help to improve insulating materials. Experimental results help to fine-tune simulations therefore more accurate simulations can be performed in the future. In addition to the presented results the tasks of further research were also defined.
$15 \mathrm{~S}$

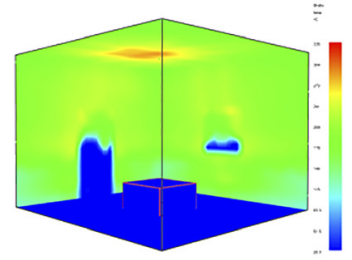

$30 \mathrm{~s}$

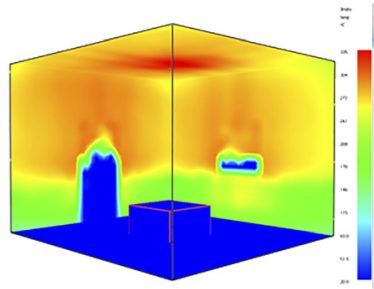

$45 \mathrm{~s}$

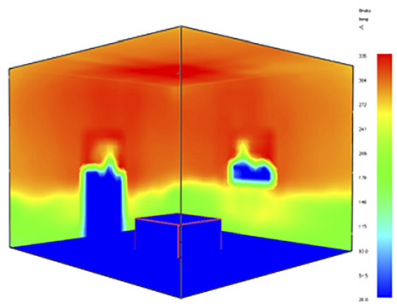

$60 \mathrm{~s}$

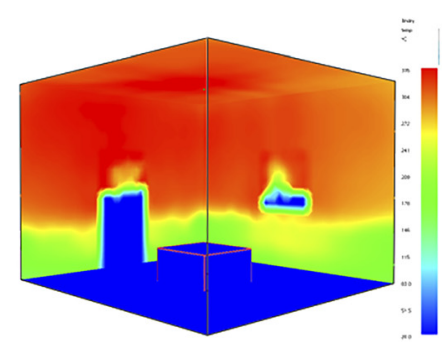

Fig. 9. Temperature rise in case of the first simulation model 
$15 \mathrm{~S}$

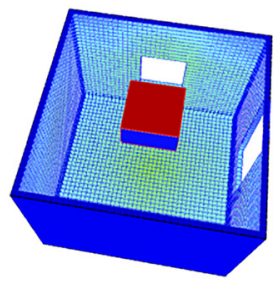

$30 \mathrm{~s}$

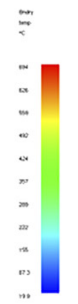

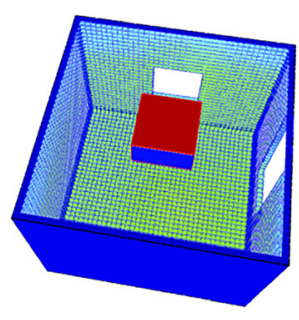

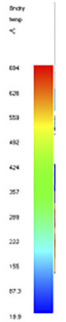

$45 \mathrm{~s}$

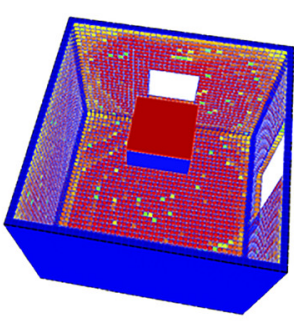

$60 \mathrm{~s}$

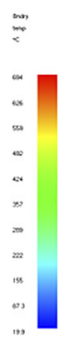

Fig. 10. Temperature rise in case of the second simulation model

\section{REFERENCES}

[1] D. Bozsaky, "Recent studies on thermodynamic processes in nanoceramic thermal insulation coatings", Pollack Period., vol. 14, no. 1, pp. 107-116, 2019.

[2] MSZ 7573: 2015, Thermal insulation products for buildings, Factory made expanded polystyrene (EPS) products (in Hungarian), Magyar Szabványügyi Testület, 2015.

[3] L. G. Takács, "Fire Cases in Low Energy Buildings" (in Hungarian), Védelem Online, Tüz-és Katasztrófavédelmi Szakkönyvtár, 2013. [Online]. Available: http://www.vedelem.hu/letoltes/document//9alacsony-energiaigenyu-epuletek-tuzeseti-tapasztalatai.pdf. Accessed: Dec. 1, 2020.

[4] M. Lestyán, "Fire protection issues of thermal insulation systems" (in Hungarian), Védelem Online, Tüz-és Katasztrófavédelmi Szakkönyvtár, 2015. [Online]. Available: http://vedelem.hu/files/ UserFiles/File/konf2012/lakitelek/Lestyan_Hoszigetelo_rendszerek_ tuzvedelmi_kerdesei.pdf. Accessed: Dec. 10, 2020.

[5] R. Kuti and G. Zólyomi, "Hazards from smoke during fires" (in Hungarian), Védelem Tudomány: Katasztrófavédelmi Online Tudományos Folyóirat, vol. 3, no. 2.III/2, pp. 67-76, 2019. [Online]. Available: http://www.vedelemtudomany.hu/articles/05kuti-zolyomi.pdf. Accessed: Dec. 10, 2020.

[6] ISO 11925-2:2020, Reaction to fire tests, Ignitability of products subjected to direct impingement of flame, Part 2: Single-flame source test, International Organization for Standardization, 2020.

[7] G. B. Baker, Performance of expanded polystyrene insulated panel exposed to radiant heat, Fire Engineering, Research report, no. 722, University of Canterbury, Christchurch, New Zealand, 2002.

[8] P. Krause and A. Nowoświat, "Experimental studies involving the impact of solar radiation on the properties of expanded graphite polystyrene", Energies, vol. 13, no. 1, pp. 1-17, 2019.
[9] R. Coquard, D. Baillis, and D. Quenard, "Heat transfer in lowdensity EPS foams," in 12th International Meeting on Heat Transfer, Tanger, Morocco, Nov. 15-17, 2005, 2005, pp. 291-294.

[10] A. Blazejczyk, C. Jastrzebski, and M. Wierzbicki, "Change in conductive-radiative heat transfer mechanism forced by graphite microfillerin expanded polystyrene thermal insulation - Experimental and simulated investigations," Mater., vol. 13. no. 11, Paper no. 2626, pp. 1-26, 2020.

[11] B. Pukánszky and J. Móczó, Plastics (in Hungarian). Budapest: Typotex Kiadó, 2012.

[12] M. Lestyán, "Wherever we try to test, polystyrene foam is combustible" (in Hungarian), Védelem Katasztrófa-és Túzvédelmi Szemle, vol. 18, no. 5, pp. 40-42, 2011. [Online]. Available: http:// vedelem.hu/letoltes/ujsag/v201105.pdf. Accessed: Dec. 10, 2020.

[13] B. Sajadian and H. Ashrafi, "Fire performance of concrete sandwich panel under axial load", Pollack Period., vol. 15, no. 1, pp. 45-52, 2020.

[14] K. McGrattan, S. Hostikka, J. Floyd, R. McDermott, and M. Vanella, Fire dynamics simulator, User's guide. [Online]. Available: https://github.com/firemodels/fds/releases/download/FDS6.7.5/ FDS_User_Guide.pdf. Accessed: Dec. 29, 2020.

[15] X. Cheng, Y. Zhou, H. Yang, and K. Y. Li, "Numerical study on temperature distribution of structural components exposed to travelling fire," Proced. Eng., vol. 71, pp. 166-172, 2014.

[16] D. Zigar, D. Pesic, I. Anghel, and N. Misic, "Simulation of fire radiative heat flux through compartment openings using FDS," in Požární Ochrana, Ostrava, Czech Republic, Sep. 9-10, 2015, 2015, pp. 380-383.

[17] A. C. Y. Yuen, G. H. Yeoh, R. Alexander, and M. Cook, "Fire scene reconstruction of a furnished compartment room in a house fire," Case Stud. Fire Saf., vol. 1, pp. 29-35, 2014.

[18] C.-S. Ahn and J.-Y. Kim, "A study for a fire spread mechanism of residential buildings with numerical modeling," WIT Trans. Built Environ., vol. 117, pp. 185-196, 2011.

[19] FDS tutorial. [Online]. Available: https://fdstutorial.com/yourfirst-fds-simulation/. Accessed: Oct. 10, 2020. 